\title{
New Tendencies of World Economic Development and Prospects of the Russian National Economy
}

\author{
Lylova Elena* \\ Department of Management \\ Peoples' Friendship University of Russia \\ RUDN University \\ Moscow, Russia \\ lylova-ev@rudn.ru
}

\author{
Marina Ignatskaya \\ Peoples' Friendship University of Russia \\ RUDN University \\ Moscow, Russia \\ ignatskayam@mail.ru
}

\begin{abstract}
The article highlights the issue of prospects of development of the modern world economy, which can be primarily characterized as socially-oriented. In different countries, there are many examples of "points of growth" of a socially oriented economy, contributing to the development of a model of three-way interaction of public authorities, business structures and society.

Russia has its own specifics of economic development, and the effectiveness of the new (above-mentioned) economic trends is limited by the consequences of the global economic crisis of 2008. The article analyzes in detail the causes of the global financial and economic crises and their impact on the development of the Russian economy; the barriers to the development of the Russian economy are identified, and the authors propose promising directions for their solution. Having considered nature and contradictions of the modern world systemic and structural economic and financial crisis, we agreed on the main areas of their influence on further development of the Russian national economy as well as its immediate socio-economic prospects.
\end{abstract}

Keywords-Socially-oriented economy; World systemic and structural financial and economic crises; Public-private partnership; Corporate social responsibility; Socio-economic partnership

\section{INTRODUCTION}

There is a need to clearly define that under social market economy of the Information Age we mean primarily that the state (at all levels of power) is carrying out a strong social policy and permanent improvement of population's quality of life through the implementation of effective, i.e. based on intensive factors of economic growth and the tertiary sector of the economy, subject-object governing interactions and mutual influences (up to mutual infiltration and, on this basis, the qualitative changes within the transition to a new stage of development).

By the socially oriented market economy on the boundary of $20^{\text {th }}-21$ st centuries is primarily meant an implemented model of the so-called new economy, with the essential foundation which supports the regime of economic democracy (participative economy), reinforced by strong social policy of the state.

The present stage of development of the world economy under the Information Age, is penetrated with systemic and structural financial and economic crises, and today inevitably gives rise to emergence of previously unknown trends in the sphere of public administration, economic management and in general, in the systems of organization, management and operation. Hence the emergence of new patterns of development which in its turn enhanced the emergence of postindustrial information society model or a model of the new economy.

\section{NEW TENDENCIES OF WORLD ECONOMY AND RUSSIAN SOCIO-ECONOMIC SPECIFICS}

Socially-oriented entrepreneurship throughout the world is aimed at solution of socially important problems and is developing during not less than three and a half decades. But for Russia, it is an undoubted innovation while maintaining a socio-psychological distrust of citizens to participation of commercial organizations in addressing socio-economic problems of society in general, and also holds persistent traditional stereotypes that the state is the only responsible entity (although more than $40 \%$ of Russian citizens believe that to take part in solving problems of society should both - state and business structures) [1]. So the current status quo allows to work out establishment of the due "rules of game" with state and municipal authorities, and furthermore contributes to enabling capitalization of business reputation and image, which has a positive effect on development of consumer loyalty.

Development of socio-economic partnership (SEP) is being filled with new content, resulting from addition to power and business structures partnership new party - the public. The concept of SEP compared to public private partnership (PPP) and social partnership more relevantly reflects emerging trends of formation and development of interaction of government and business in socio-economic sphere with public participation. Therefore, only SEP actually gives insight into how it is through initiatives, innovation and resources of all participants-partners to solve problems, socially significant for society as a whole. "Growth points" of SEP serve, first and foremost, for emergence of social entrepreneurs, emergence of venture philanthropy, PPP mechanism transformation to public private social partnership (PPSP), GR-technologies (government relations technologies) development, and use of crowd-sourcing. Note that for Russia social entrepreneurship is a relatively new phenomenon, whereas abroad experience of social entrepreneurship began piling up already since 1980's. So, such social business structures as the Grameen Bank, 
Sekem, the Mondragón Corporation and other organizations supported these initiatives worldwide and their contribution to economic and social development of a country are highly appreciated not only by national public but also by the entire international community.

The impetus for development of venture philanthropy was an attempt to bring business experience to non-profit sector, based on understanding that not systemic and not targeted donations may not be effective. Over time, it has become more evident for businesses that the situational approach to solving social problems does not always lead to tangible progress.

Focused impact of a certain business structure on a particular area of social sphere (compared with situational decisions) is much more appropriate for Russian reality.

A new stage of development of PPP becomes PPSP public private social partnership. Currently, researchers and practitioners agree that PPP in social sector requires both special conditions for its realization, and special criteria for selecting and evaluating the results of its activities [2].

GR-management is increasingly developing — that is managing interaction of business structures with public authorities, aimed at forming a constructive dialogue between them. A relatively new technology that involve active public with strong civil position to address the pressing problems of the state, becomes a crowd-sourcing. Crowd-sourcing is a voluntary and self-organized activities of many people, aimed at solution of specific tasks by using information technologies. The subject of crowd-sourcing advocates uniting people, professionals, amateurs or enthusiasts, and the purpose of such associations is to solve any specific problem of socio-economic sphere by means of collective intelligence forces and collective enthusiasm, often at no charge. Individual voluntary desire of each participant to do something socially useful to see their ideas embodied, desire to help, make or improve something becomes crucial motivation of such activities. Crowd-sourcing can help both in solving socially significant socio-economic problems, and also it can successfully become a promising improvement of organizational management system, which in turn will have a positive impact on organizational performance results. When implementing socio-economic programs, a certain part of population concerned with crowd-sourcing is able to not just control activities of business entities and organs of state and municipal authorities, but also to participate directly in implementation of these programs, thereby possibly reinforcing positive synergistic effect of interaction between power and business structures, which is already available as part of these programs. Organizational-technical basis of crowd-sourcing is becoming ICT (information and communication technologies), submitted by social networks in Internet, as well as applications on smartphone. Currently a specialized social network is running, users of which, indifferent to certain problems of modern city people, are able to communicate and to unite to solve various problems (both local and global), as well as interact with authorities.

Generalizing SEP "growth points" by one summarizing transformation vector, we can specify that by means of SEP an extension of the concept of corporate social responsibility (CSR) to the notion of "socio-economic partnership" of business and authorities with public participation naturally happens.

Such a partnership is defined as a form of cooperation between governmental and business structures, as well as public, due to common interests of all parties involved. It is aimed at solving of socio-economic problems and joint achievement of socially and economically important goals. CSR of business, as practice shows, on the contrary, in some cases, is not a private entrepreneurial initiative. It is a result of pressure either of power structures and in general governing subject-object control actions of state, or - of realization of one's own, often purely mercenary interests. SEP within system of "power-business-society (people)" is designed to bring out tripartite relations to a new level, where population is both, an actor, and an object of socio-economic activities at the same time. That is, on the one hand, needs of population and socioeconomic problems of state and society become an object of SEP between government and business structures; and on the other, people can speak in such relationships as an active actor.

\section{WORLD SYSTEMIC AND STRUCTURAL FINANCE AND ECONOMIC (2008) CRISIS AND THEIR IMPACT ON THE DEVELOPMENT AND PROSPECTS OF THE RUSSIAN NATIONAL ECONOMY}

Nobel Laureate J. Stiglitz has already counted about one hundred of financial and economic crises within the framework of modern world economy in the period of 1980-1990-ies, which he tied in first place, with two main reasons liberalization of financial flows, as well as weakening of state regulation in financial sector [3]. With this view it is difficult to disagree; it can only be added by underlying trends in the world economy which strengthen these two causes. We are talking about that the modern financial and economic crises have become permanent and inherent to development of the world economy period of the end of $20^{\text {th }}$ up to early $21^{\text {st }}$ century. They share a number of new features that have arisen in the context of Information revolution and intensified globalization processes. First of all, fundamental reasons of modern crises include accelerating disproportionate dynamics of constituent parts of functional social capital, outstripping its accumulation in a form of cash, compared with material capital along with an overall unevenness of financial globalization processes [4]. Since the needs of real economy in a monetary loan capital are objectively limited by the size of fixed capital and working capital maintenance technology, as well as differences in periods of their circuits, advanced monetary capital accumulation is accompanied by increasing its application outside the realm of commodity production and circulation (the share of loan capital, operating outside the framework of real economy in the developed countries, is ranging from $1 / 2$ to $3 / 5$ ). Their specific feature has become being separated from real capital circulation, since complex operations outside real economy provide maximization of profits, especially through speculative stock deals. A direct consequence becomes creating "financial bubbles" periodic confront with which was necessary in order to align capitalization of stock markets with the magnitude of the real economy and capitals engaged in it. Structural changes in operating capital, accelerated by decisions of the Jamaican 
currency conference of 1970-ies, were accompanied by deregulation of financial markets and credit systems, first in the United States and later in Europe and Asia. Thus, the neoliberal model of development has led to massive deregulation of international financial markets and to massively "inflated" financial and credit "bubbles", which as a result were pulling market capitalization of firms down.

Another major cause of massive financial and economic crisis, exacerbating its destructive manifestations in world economy at the turn of $20^{\text {th }}$ and $21^{\text {st }}$ centuries, has become significant changes in dynamics of cyclical development. They found their manifestation in the fact that phase of crisis and falling production has given way to a slowdown in growth. These shifts were due to interaction between methods of state regulation of economy and market mechanisms. They have contributed to more sustainable growth rates. However, the following stake made on neo-liberalism (up to market fundamentalism) and market economic and regulatory instruments with priority of market proposal led eventually to exacerbating of economic imbalances. In future, as practice shows, this very stake on expansion of consumer demand and strengthening of social policies contributed to economic growth in the developed countries and, in particular, in the United States. However, with the following return to the model of neo-liberalism and to "economy of market offer" crisis began to grow again and became endemic, especially as current demand expanded at the expense of future incomes of clients without proper security. The situation was aggravated by growth of mortgage, often also not being secured. The overall result of all the above trends became financial crisis, which took the nature of economic and seized all national economic systems.

As regards the impacts of global systemic and financialeconomic crises (especially of 2008) on the problems of economic development of the Russian national economy, the situation is also characterized by a number of specific features. Although in the pre-crisis period Russia has gained significant reserves, but this didn't save from severe crisis, because all objective reasons have retained their value. The real threat of crisis was not adopted in calculation, especially in view of unprecedented increase in oil prices in the period, and illusion of saving them dominated. In addition, negative role was played by credit debt of the largest Russian banks to their foreign creditors, with the result that there was a sharp rise in foreign debt. In terms of mass depreciation on stock markets of securities exchanges and reducing liquidity the Russian borrowers found themselves on the verge of default. Finally, crucial role was played by the preservation of backward production structure, because since the beginning of the 1990's and before the latest financial crisis Russian authorities have not embarked on massive economic modernization and raw materials orientation retained in its full value (in Russia share of labor, capital and natural resources in structure of production factors, as well as share in structure of industries knowledge and information capacities factor is so far below than in developed countries, in three times) [5].

Anti-crisis actions in Russia were carried out mainly due to massive financial allocations, which accounted for nearly a quarter of the national GDP, while their very irrational use (the fundamental economic laws were not, as previously, taken into account, namely that production without realization of production through effective market demand is absolutely impossible). In addition, in structure of anti-crisis allocations the action to save the banking system dominated, but big businesses rather than supporting production used them to cover their costs of external debt repayments. At the first stage of anti-crisis measures a portion of loans the Central Bank gave to large banks without any mortgages, assuming the cost of insuring losses on interbank lending. As a result, the country's international reserves have declined substantially, with part of them being used for operations in stock and currency markets or transferred abroad. "Bad debts" or "bad assets" began to grow in Russian banking system as a result of devaluation, capitalization decrease and growth of defaults on loans. As a result, demand continued to decline, with all negative consequences, and crisis continued to worsen. Although social measures had been officially declared as top priority, they did not correspond with other articles of reproduction balances, and Russian state budget deficit was financed from contingency fund. Ruble devaluation was conducted for export promotion at the beginning of ruble devaluation it was smooth, but then (2014) took place in sharp form when dollar came close to 80 rubles. Pending tax reform (as part of a strong social policy) still has not been carried out, without which solution to the problem of demand becomes impossible. However, instead of socially directed policy, increases in public works, creating new jobs and increasing unemployment benefits, for today we have growth in number of absolutely poor (increase by 3.5 million persons for three year period of 2014-2016).

Thus, it is absolutely obvious that in current Russian conditions all the same structural and institutional modernization of economy as a whole are essential (which was not carried out) on basis of competent and effective economic and social policies, adopting tough measures to counter inflation, which contributes to deepening of crisis. However, this objective need is still being stubbornly resisted by economic self-interest of the Russian elite and mass corruption in power structures.

Current state of affairs with the after-effects of financial and economic crisis in Russia is characterized by leading Russian experts from the Center for Development of Higher School of Economics (Moscow, Russia) quite pessimistically because the current model of economic growth completely exhausted itself [6]. According to the expert's opinion, which is difficult to challenge, return to economic growth in the current period without external positive shocks along with radical institutional measures is impossible. If in the shortest period there will not be guaranteed transition to a fundamentally new model of growth, urgent need to navigate to which was obvious still a dozen and a half years ago, and the fundamental principles of which we reviewed in the third section of this article, then already in 2018 , it will be possible to talk about a lost decade for Russia (on the basis that none of the key problems of economic growth in 1990s-2000s was not resolved at the root).

The main trouble of the Russian economy lies in the fact that the urgent need for large-scale modernization processes, which stood in full especially sharp in the face of global crisis 
of 2008, further very quickly waned in force of rising trend in oil prices, which is why already in 2015, the Russian economy decreased by $3.7 \%$ [7]. And although in 2016, there was a "suspension of recession", but it is temporary due to permanent continuing compression of domestic demand in an environment where structure remains "bad" (extensive inherently).

According to respondents of the HSE's economists, in 2017, in Russia it is possible to switch to weak growth of $1 \%$, and only by 2020 it will become possible to get closer to the pace of growth of $2 \%$ [8]. The main factor of economic growth in the Higher School of Economics is called creation of real conditions for reviving entrepreneurial activity, and as the driving force of a modern market economy entrepreneurial spirit is considered (this growth model tends to conceptual approaches in the spirit of market fundamentalism and has already been tested in Russia in the 1990-ies). Even according to the International Monetary Fund (IMF) forecast, Russian economy could grow by only $1.5 \%$, unless priority of structural reforms implementation (and similar assessments are contained in the forecast of the Russian Ministry of Finance up to 2030).

At the end of 2016 official authorities (represented by the head of Russian Central Bank E. Nabiullina) made an important statement about "a gradual transition to the new model of Russian economy development". In the context of a continuing trend of falling oil prices, stake is made on other growth factors; and it is recognized that economic recovery may be prolonged in time. It is this result of socio-economic development of the country that is recognized as the most important outcome of adaptation of Russian economy to the new conditions. The former model, the basis of which was formed by export of raw materials and boosting consumption, including through consumer lending, has entirely exhausted its potential, which is manifested in growth attenuation even in the years before crisis and falling oil prices. Head of the Central Bank has also made a signed, in our view, recognition, namely that in absence of structural changes Russian economic growth rates in 2017, and in subsequent years will be below $2 \%$ while preserving fragile (uneven) situation in different sectors of economy. Main task of building a new model of economy of the Russian Federation is declared as maintenance of transition to investment-saving model in which savings are turned into investments, as well as ensuring stability in financial conditions in order to develop domestic sources of investment. Transition of economy to investment model became the basis of the target scenario of socio-economic development of the Russian Federation for the period up to 2035, drawn up by the Ministry of Economic Development. In this scenario, to ensure acceleration of GDP growth up to $4 \%$ by 2019 should be used such factors as: improving business climate, support for noncommodity exports (outside raw materials specialization), cost reduction, revenue growth of companies. In our opinion, in case of even partial implementation of such a model, based on experience of development of Russia in modern conditions since the early 1990-ies, we can conclude that its inevitable social consequences are going to be drastic, when shift of model traditionally have to pony up the population, ordinary
Russians with increased inflation and further depreciation of their incomes and savings.

\section{CONCLUSION}

We can say that the modern market economy of a democratically developed state is obliged to be socially oriented. Some examples of even underdeveloped countries demonstrate a phenomenal ability to solve social problems by economic means (Grameen Bank). Russia is no exception. However, the development of a socially oriented economy in Russia is hampered by the serious consequences of the financial and economic crises. The accelerated implementation of the catch-up development model requires, as can be seen from the best foreign experience, the rational distribution and use of limited resources on the basis of a rigid system of state economic regulation and regulation of economic activities, as well as the subordination of initiatives of business structures and the public aimed at solving socio-economic problems of the state.

Thus, the main conclusion of the study is that in order for Russia to implement the strategy of catching-up development, first of all it is necessary to carry out reforms that contribute to the development of a socially oriented economy, involving in the process of transformation both the business structure and society, based on successful international experience.

\section{ACKNOWLEDGMENT}

The publication was prepared with the support of the «RUDN University Program 5-100».

\section{REFERENCES}

[1] Federal State Statistics Service. n.d. "Main socio-economic indicators of living standard of population," Accessed January 23, 2018. http://www.gks.ru/.

[2] L.M. Surhone, M.T. Tennoe, and S.F. Henssonow, Public/Social/Private Partnership, Betascript publishing, 2011.

[3] "Modern problems of development. Materials of theoretical seminar," Moscow: Primakov National Research Institute of World Economy and International Relations of Russia Academy of Sciences, 2010.

[4] A.V. Tutunnik, "The causes of the crisis and scenarios out of it. Money and Credit," vol. 10, pp. 31-33, 2009, Retrieved from http://cbr.ru/eng/publ/?PrtId=moneyandcredit.

[5] A.I. Dinkevich, "The global financial and economic crisis (experience of the structural-functional analysis)," Money and Credit, vol. 10, pp. 2330, 2009 Retrieved from http://cbr.ru/publ/MoneyAndCredit/archive_09.pdf.

[6] Development Center of Higher School of Economics. Comments. Macroeconomics, "Comments about state and business," vol. 119, pp. 316, 2016. Accessed March 16, 2018. https://dcenter.hse.ru/data/2016/08/26/1121352151/KGB_119f.pdf .

[7] The World Bank, "Project \& operations," Accessed March 15, 2018. http://www.worldbank.org.

[8] Joint Economic and Social Data Archive, "The economic statistical base of the Russian Federation," Accessed February 17, 2018. http://sophist.hse.ru/hse/nindex. shtml. 